\title{
Modeling Adjuncthood - An Overview OF Incomplete Predication Verbs IN Albanian
}

\author{
Eljana Mosko, PhD
}

Katerina Vasili

Evanthia Baruta

\author{
University "Eqrem Çabej" of Gijrokastra, Albania \\ emosko@uogj.edu.al; kvasili@uogj.edu.al; evanthiajovani@yahoo.gr
}

\author{
Doi:10.5901/ajis.2016.v5n3s1p64
}

\section{Abstract}

The principal objective of this paper is to demonstrate some groups of intransitive verbs in Albanian which require a word or phrase to complete the predicate and make sense of the sentence. It is the case of adjuncts and complement/adjunct distinction. There are different proposals on the adjunct notion. This holds both in syntax and semantics. Our aim is to investigate how the adjunct notion is applied in Albanian linguistics; there are brought evidences from the cases when adjuncts are used as an optional part of a sentence or phrase that, if removed will not otherwise affect the remainder of the sentence and the cases used as an obligatory part of the sentence or verb phrase. Adjuncts are said not to fulfil selection requirements. Instead, it is thought that adjuncts themselves select the type of their host. For this reason we present evidence from Albanian intransitive verb groups that consider adjuncts as complementary class. The research is based on the data gathered from all the intransitive verbs given in the Dictionary of the Albanian Language (2006).

Keywords: adjunct, linguistics, argument, intransitive verb

\section{Introduction}

Theories of argument structure assume that arguments are necessary constituents; deleting them lead to ungrammaticality. Adjuncts on the other hand, may be said to fulfil selectional requirements (Hole, 1-33). The adjunct clauses are optional. Their omission does not lead to ungrammaticality of the sentence. Thus arguments are verbheaded, whereas the use of adjuncts is independent of particular verbs. But adjuncthood is more complex than that. There is a trend to level out the difference between arguments and adjuncts, such that adjuncts are increasingly seen to be just arguments of a special kind (Haspelmath: 2014). It is the case of adjuncts/complements which are selected by intransitive verbs of incomplete predication. Thus the difference between arguments and adjuncts disappears since adjuncts may be viewed as semantic arguments by some intransitive verbs whose meaning is not complete; there is needed an extra element for the verb to be grammatically correct (Hole, 2). Intransitive verbs indicate complete actions and their argument structure bears only one external argument, the subject which expresses a defining element of the process or state designated by the verb (Farrell 2005, 31). The use of other elements would serve the purpose of making the sentence more complete. We have recorded all intransitive verbs from entries in the Dictionary of Albanian Language (2006) and we have grouped the intransitive verbs, which except for the subject, need another constituent in order to be grammatically correct. It may be an adverbial of place, time or manner.

\subsection{An overview of incomplete predication verbs}

Argument structure has been widely studied as a core part of Generative Grammar due to the importance that the concept has developed over the last years.

Dowty (2000: 53) states that in syntax, an adjunct is an "optional element", they are freely deletable without loss of formedness or grammaticality, while a complement is an "obligatory element" whose presence in a given clause is required by some predicate. In semantics, an adjunct "modifies" the meaning of its head, while a complement "completes" the meaning of its head. We have recorded the subcategorization information for all Albanian intransitive verbs and there is noted that there is a group of intransitive verbs that except for the external argument, functioning as a subject and given mainly as a NP or DP, there is also needed another constituent which is obligatory in order for the sentence to 
make sense. This is the case of adverbials, mainly locatives, whose omission make the sentence not complete. Thus these elements are semantically necessary for the verbal phrase. Such verbs are called verbs of incomplete predicativity (Hanafy: 2012) and usually express the idea of being, becoming, seeming, appearing.

\subsubsection{Analysis Result}

Based on the results given by the research in intransitive verbs, we have considered the first group of intransitive verbs of incomplete predicativity in Albanian to be the group of verbs such as: live/dwell. In Albanian linguistics the adverbials are traditionally considered as peripheral elements of the sentence, thus adjuncts (Kananaj: 2012). But a part of adverbials fill all the demands to be complements. Thus a large part is covered by the adverbials of place, the locatives (Krifka: 73). This is the case of locatives which are assumed to function as adjuncts in most of the cases but in sentences such as:

Alb: Ai banon në Tiranë.

Eng: He lives in Tirana.

If the locative in Tirana (në Tiranë) is omitted the sentence would be ungrammatical:

Alb: * Ai banon.

Eng: * He lives.

the verb live/dwell needs the PP in Tirana, otherwise the sentence is not complete. The verb shows that the argument functioning as the subject, "he" is not enough to fulfil the meaning of the verb - the need for the PP is complementary, thus "in Tirana" is a complement of the intransitive verb "to live". In Albanian, verbs such as dwell (banoj), return (kthehem), lie (shtrihet), go (shkoj) etc. are fulfilled by prepositional phrases PP or adverbials which in syntax serve as obligatory elements whereas in semantics they complete the meaning of their head (Dowty, 53:2000).

\section{Alb: Mbeta këtu/në mes të rrugës.}

\section{Eng: I was stuck here/in the middle of the road.}

In the overmentioned sentence there is used the intransitive verb stick ${ }^{2}$ (mbes) which needs to be completed by the adverbial of place "here" (këtu) or "in the middle of the road" (në mes të rrugës) in order for the sentence to be correct and complete. Thus these adverbials of place affect the verb that much, to the extent that their omission would lead to ungrammaticality. Only in a prementioned context, in which we already know what the situation is about, we may accept and consider as correct the sentence:

Alb: Mbeta.

Eng: I was stuck.

As shown by the sentences the lack of the complement (in this case a locative /adverbial of place) prepositional phrase PP, adverbial phrase AP make these sentences non grammatical. The verbs that follow share the same characteristic: dwell (banoj), lean (anoj), adhere (aderoj), stand (qëndroj), gush (buron - used with adverbial of place), exit (dal), seep (depërtoj), figure (figuroj), dig (gërmoj - when used as intransitive), enter (hy]), migrate (imigroj), live (jetoj - used with the meaning, dwell), take a shortcut (pres1 when used as intransitive) etc.

We have considered the second group of intransitive verbs of incomplete predicativity in Albanian to be the group of verbs such as: feel / work / operate (when used as intransitive), which need an adverbial / complement of manner to complete their meaning.

Alb: Djali u ndie mirë/keq.

Eng: The boy felt well /badly.

Alb: *Djali u ndie.

Eng: * The boy felt.

For the case of Albanian, only in a pre mentioned context, the conversation would be complete - in the case when the speaker and the hearer already know about the activity such as:

Alb: Ai punon. 
Eng: He works.

Alb: Ai punon si mësues.

Eng: He works as a teacher.

The constituent "as a teacher" is obligatory in order for the sentence to be semantically complete. Larson (1988: 169) states that such elements appear to share characteristics of adjuncts and arguments alike; linguists have considered them to be optional or "implicit" arguments (Roeper: 1983). Also the verb "work" can be found in following examples:

Alb: Punon në uzinë / në arë / në minierë / në arsim.

Eng: He works in the factory/ in the field / in education.

Alb: Punon mirë.

Eng: He works well.

Alb: Punon si mësues. Or the same case for the verb "serve" (shërbej)

Eng: He works as a teacher.

Alb: Shërben si mësues

Eng: He serves as a teacher.

*Punon.

${ }^{*}$ Works.

* Shërben.

* Serves.

Alb: Biblioteka punon gjithë ditën.

Eng: The library functions all day.

Alb: * Biblioteka punon.

Eng: * The library functions.

The verb "sound" (tingëllon) is also complemented by an element functioning as an adverbial of manner.

Alb: Kjo fjali tingëllon bukur.

Eng: This sentence sounds lovely.

Alb: * Kjo fjali tingëllon.

Eng: * This sentence sounds.

Based on the intransitive verbs consulted from the Dictionary of Albanian Language there was noted the group of co-verbs, such as: co-exist (bashkëekzistoj), cohabit (bashkëbanoj, bashkëjetoj), co-govern (bashkësundoj), converse (bisedoj - when used as intransitive), dialogue (dialogoj), fight in unison (dyluftoj), communicate (komunikoj - when used as intransitive), cooperate (kooperoj), costar, co-author etc. which in most of the cases are complemented by prepositional objects. If these elements are omitted the sentence would result to be incomplete, unclear and grammatically incorrect.
Alb: Bashkëjeton me prindërit.
Eng: He cohabits with his parents.
Alb: Komunikojnë me lexuesin.
Eng: They communicate with the reader.
Alb: * Bashkëjeton.
Eng: * Cohabit.

The omission of the prepositional object results in ungrammaticality. This clearly points out the fact that it is part of the subcategorization frame of the verb.

\section{Concluding Remarks}

It is commonly assumed across the language sciences that some semantic participant information is lexically encoded in the representation of verbs and some is not. The distinction between complements and adjuncts has a long tradition in grammatical theory. The subcategorization frame of the verb includes the arguments of it. In the case of intransitive verbs the subcategorization frame selects only one argument, the subject which expresses a defining element of the process or 
state designated by the verb. For the case of verbs of incomplete predication except for the external argument, functioning as a subject and given mainly as a NP or DP, there is also needed another constituent which is obligatory in order for the sentence to make sense. This is the case of adverbials, mainly locatives, whose omission make the sentence not complete.

\section{References}

Fjalori i Gjuhës Shqipe (Dictionary of Albanian Language) (2006). Akademia e Shkencave, Tirana

Farrell, P., (2005). Grammatical relations. Oxford: Oxford University Press

Kananaj, A, (2012). Funksionet e rrethanorit në gjuhën shqipe (Functions of adverbial in Albanian). Doctoral thesis, University of Tirana

Dowty, David. The Dual Analysis of Adjuncts/Complements in Categorial Grammar. [Online] Available: http://www.ling.ohiostate.edu// dowty/papers/degruyter.8x11.pdf (July 27, 2016)

Hanafy, A. Iman. (2012), English Grammar 2. [Online] Available: http://www.olc.bu.edu.eg/olc/images/fart/122.pdf (July 21, 2014)

Haspelmath, Martin. (2014), Arguments and Adjuncts as Language-Particular Syntactic Categories and as Comparative Concepts, Volume 12 Issue 2, Max Planck Institute for Evolutionary Anthropology, Linguistic Discovery Dartmouth College Library. [Online] Available: http://journals.dartmouth.edu/cgibin/WebObjects/Journals.woa/1/xmlpage/1/article/442?htmlOnce=yes (July 27, 2016)

Hole, Daniel. Arguments and adjuncts. [Online] Available: http://www.uni-stuttgart.de/ilg/institut/mitarbeiter/hole/schriften/Holetoappeara DRAFT.pdf (July 27, 2016)

Krifka, Manfred. (2001), Predicates, Modifiers, Definite NPs, X-bar Theory, and Types, [Online] Available: http://amor.cms.hu-berlin.de/ h2816i3x/Lehre/2000_Semantics/Semanticsl-05.pdf (March 13, 2012)

Larson, K. Richard. (1988), Implicit Arguments In Situation Semantics, [Online] Available: http://semlab5.sbs.sunysb.edu/ rlarson/ larson88iaiss.pdf (July 27, 2016) 